\title{
Economic Feasibility of Strontium-90 Fueled Heaters for Use in Cold Regions
}

by

W. E. Sande

R. L. Aaberg

February 1978

Prepared for the

U.S. Department of Energy

under Contract EY-76-C-06-1830 


\title{
NOTICE
}

This report was prepared as an account of work sponsored by the United States Government. Neither the United States nor the Department of Energy, nor any of their employees, nor any of their contractors. subcontractors, or their employees, makes any warranty, express or implied, or assumes any legal liability or responsibility for the accuracy, completeness or usefulness of any information, apparatus, product or process disclosed, or represents that its use would not infringe privately owned rights.

The views, opinions and conclusions contained in this report are those of the contractor and do not necessarily represent those of the United States Government or the United States Department of Energy.

\author{
PACIFIC NORTHWEST LABORATORY \\ operated by \\ BATTELLE \\ for the \\ UNITED STATES DEPARTMENT OF ENERGY \\ Under Contract EY-76-C-06-1830
}
Printed in the United States of America Available from
National Technical Information Service United States Department of Commerce
5285 Port Royal Road
Springtieid. Virginia 2215T

Price: Printed Copy $5 \_$; Microtiche $\$ 3,00$

$\begin{array}{cc} & \text { NTIS } \\ \text { *Pages } & \text { Selling Price } \\ 001-025 & \$ 4.50 \\ 026-050 & \$ 5.00 \\ 051-075 & \$ 5.50 \\ 076-100 & \$ 6.00 \\ 101-125 & \$ 6.50 \\ 126-150 & 57.00 \\ 151-175 & 57.75 \\ 176-200 & \$ 8.50 \\ 201-225 & \$ 8.75 \\ 226-250 & \$ 9.00 \\ 251-275 & 510.00 \\ 276-300 & 510.25 \\ & \end{array}$




\section{8}

ECONOMIC FEASIBILITY OF STRONTIUM-90

FUELED HEATERS FOR USE IN COLD REGIONS

by

W. E. Sande

R. L. Aaberg

February 1978

BATTELLE

Pacific Northwest Laboratories

Richland, Washington 99352 


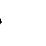

.

.

. 


\section{SUMMARY}

The objectives of this study are to conceptualiy design and obtain cost estimates for various radioisotope fueled heating systems for use in potential cold regions applications, and to determine the economic feasibility of radioisotope fueled heaters by comparing them to fuel oil systems. The applications have been identified and grouped, according to thermal output: 1) $1 \mathrm{kWt}$ septic tank heaters, wel1-head heaters, heaters to assist operation of sewage lagoons, and 2) 7 or $12 \mathrm{kWt}$ potable water system heaters. Potentially economic locations for these heaters are in remote Alaskan communities of 50 to 200 residents, where fuel oil prices and reliability requirements are high.

The advantages of radioisotope energy systems are: refueling only every five to ten years, low maintenance requirements, and high reliability. These systems consist of a radioisotope heat source, radiation shielding, and heat transfer and energy converting devices. Their safety has been demonstrated in the past in powering both remote weather stations and navigational aid systems.

Strontium-90 is the radioisotope heat source used in the heater conceptual designs and is presently available from the Hanford Waste Encapsulation and Storage Facility (operated for the Department of Energy by Rockwel1 International, Hanford Operations) through the Isotope Sales Division at Oak Ridge National Laboratory, Oak Ridge, Tennessee. The heat generating material is contained in a double-walled stainless steel capsule which is approximately $20 \mathrm{in}$. long and $2.6 \mathrm{in}$. in diameter. The heat generation rate is about $1 \mathrm{kWt}$ per capsule.

Two basic conceptual heat designs were considered: a heat source and radiation shielding with no external heat transfer equipment, and a heat source and radiation shie?ding with external heat transfer equipment. Costs for both conceptual designs were estimated for heater sizes of $1 \mathrm{kWt}, 7 \mathrm{kWt}$, and $12 \mathrm{kWt}$. The major costs were for the heat source and equipment. One capsule (1 kWt) is equivalent to 150,000 curies of strontium-90 $\left({ }^{90} \mathrm{Sr}\right)$. The present government price for this encapsulated ${ }^{90} \mathrm{Sr}$ is $10 \notin /$ curie fob 
Hanford, Washington; thus, one capsule would cost $\$ 15,000$. The costs for $7 \mathrm{kWt}$, or 7 capsules, would be $\$ 105,000$ and for $12 \mathrm{kWt}$, or 12 capsules, $\$ 180,000$. The approximate costs are summarized below based on system size. Fuel oil system costs, based on \$1.50/gal fuel oil, are also given for comparison. Total capital cost for the radioisotope systems includes equipment, transportation and isotope fuel. Cesign, development, and licensing costs are not included. Annual cost includes both a pro-rated annual capital cost and operating costs.

\begin{tabular}{|c|c|c|c|c|}
\hline System Size & $\begin{array}{l}\text { Total Capi } \\
\text { Radioisotope } \\
\text { System }\end{array}$ & $\begin{array}{c}1 \text { Cost, } 1976 \$ \\
\text { Fuel } 0 i 1 \\
\text { System }\end{array}$ & $\begin{array}{c}\text { lotal Annual } \\
\text { Radioisotope } \\
\text { System }\end{array}$ & $\begin{array}{c}\text { st, } 19 / 6 \$ \\
\text { Fuel } 0 i 1 \\
\text { System }\end{array}$ \\
\hline $1 \mathrm{KWt}$ & 50,000 & $4,000-10,000$ & 8,000 & $2,000-6000$ \\
\hline $7 \mathrm{kWt}$ & $170,000-180,000$ & 10,000 & $30,000-40,000$ & 11,000 \\
\hline $12 \mathrm{kWt}$ & $260,000-310,000$ & 10,000 & $40,000-50,000$ & 11,000 \\
\hline
\end{tabular}

Radioisotope heaters are much more expensive than fuel oil systems. To assist in cost analysis, the costs can be reduced to overall equivalent fuel oil price, i.e., the price of fuel $0 i 1$ that would make radioisotope systems compete equally with fuel oil systems. These are summarized below. Isotope fuel costs have been factored out to show their contribution.

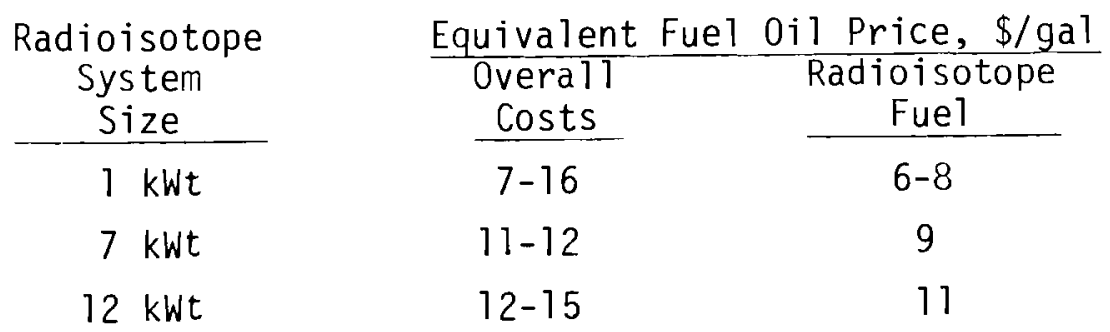

A representative fuel $0 i 1$ price for remote locations in 1976 can be taken as $\$ 1.50 /$ gal; thus, fuel oil prices must increase dramatically before radioisotope systems can be economically competitive. If a 10\% inflation rate of fuel $0 i 1$ prices over 10 years is assumed (10 years was taken as both radioisotope and fuel $0 i 1$ system 1 ife), the average effective fuel oil price would be $\$ 2.50 / \mathrm{gal}$, which is still much less than the lowest radioisotope system overall cost in equivalent fuel oil price of $\$ 7 / \mathrm{gal}$. 
As shown above, the radioisotope fuel costs contribute $50 \%$ or more to the overall cost. Thus, an effective method to make a substantial reduction in radioisotope system cost would be to lower the strontium price from $10 \notin /$ curie. To make the radioisotope system economically competitive with $\$ 1.50 /$ gal fuel 011 , the price would need to be lowered to $0 \$ /$ curie. Since the primary reason for encapsulating the strontium-90 is for nuclear waste management and not for providing radioisotope heat sources, a price reduction may not be entirely out of the question, but this must be decided by various government agencies who are in charge of the strontium, and by potential user agencies or potential user private groups. A primary consideration for the potential user is that the present supply of strontium-90 is 1 imited to about 800 capsules; a future supply for system refueling may be available only at a price greater than $10 \$ /$ curie.

In conclusion, radioisotope heaters will not be economically competitive with fuel oil systems unless one or more of the following situations occur:

- the price of strontium-90 is reduced below 10\$/curie,

- fuel oil prices increase significantly, or

- for a particular application, the reliability or adaptability of a fuel oil system is unacceptable and a radioisotope system is satisfactory. 
CONTENTS

SUMMARY . . . . . . . . . . . . . . . . . . . . . . . . . . . .

LIST OF FIGURES. . . . . . . . . . . . . . . . . . . . vii

LIST OF TABLES . . . . . . . . . . . . . . . . . . . . . . . . vii

1.0 INTRODUCTION . . . . . . . . . . . . . . . . . . . . . . . . 1

2.0 RADIOISOTOPE ENERGY SYSTEMS . . . . . . . . . . . . . . . . 3

2.1 RADIOISOTOPE HEAT SOURCES . . . . . . . . . . . . . . 3

2.2 LICENSING REQUIREMENTS . . . . . . . . . . . . . . 4

2.3 SYSTEM DESCRIPTIONS . . . . . . . . . . . . . . . 5

3.0 COLD REgiON RAdIOISOTOPE HEATERS . . . . . . . . . . . . 7

3.1 STRONTIUM-90 HEAT SOURCE . . . . . . . . . . . . . . . . . 7

3.2 POTENTIAL APPL ICATIONS . . . . . . . . . . . . . . . . . . 9

4.0 ECONOMICS. . . . . . . . . . . . . . . . . . . . . . . . 13

4.1 TRANSPORTATION OF RADIOISOTOPE FUEL. . . . . . . . . . . 13

4.2 RADIOISOTOPE HEATERS. . . . . . . . . . . . . . 16

4.2.1 1 kwt Heaters. . . . . . . . . . . . . 17

4.2.2 $12 \mathrm{kWt}$ Heaters . . . . . . . . . . . . 20

4.2.3 12 kWt Combination Radioisotope/Fuel 011 Systems. . . 21

4.3 FUEL OIL SYSTEMS . . . . . . . . . . . . . . . . 26

4.3.1 12 kWt Heaters . . . . . . . . . . . . . 27

4.3.2 1 kWt Heaters. . . . . . . . . . . . . . . 28

4.4 ECONOMIC COMPARISONS. . . . . . . . . . . . . . . . . . . 29

5.0 CONCLUSIONS

REFERENCES . . . . . . . . . . . . . . . . . . . . . . 39

ACKNOWLEDGMENTS. . . . . . . . . . . . . . . . . . . . . 41 


\section{FIGURES}

1 WESF Strontium Fluoride and Cesium Chloride Capsule Characteristics. 8

2 Septic Tank Heater. . . . . . . . . . . . . . . . . . 19

3 Water Storage Heater $-12 \mathrm{kWt}$. . . . . . . . . . . . . 22

\section{$\underline{\text { TABLES }}$}

1 Heat Requirements for a 200,000 Gal Water Storage Tank . . . 10

2 Transport Casks . . . . . . . . . . . . . . . . 15

3 Costs to Transport Radioisotopes . . . . . . . . . . 15

4 Preliminary Cost Estimate for 1 kWt Strontium-90 Heater - No

External Heat Transfer Equipment . . . . . . . . . . . 17

5 Preliminary Cost Estimate for 1 kWt Strontium-90 Heater -

Externa 1 Heat Transfer Equipment . . . . . . . . . . 18

6 Preliminary Cost Estimate for a $12 \mathrm{kWt}$ Strontium-90

Water Heater, No External Heat Transfer Equipment. . . . . . 20

7 Preliminary Cost Estimate for a 12 kWt Strontium-90

Water Heater, External Heat Transfer Equipment . . . . . . 23

8 Preliminary Cost Estimate for a 7 kWt Strontium-90 Water Heater, No External Heat.Transfer Equipment. . . . . . 24

9 Preliminary Cost Estimate for a 7 kWt Strontium-90 Water Heater, External Heat Transfer Equipment . . . . . . 25

10 Cost Estimate for a $12 \mathrm{kWt}$ Fuel $0 i 1$ Water Tank Heater . . . . 27

11 Comparison Between Total Capital and Annual Costs of Isotope and Fuel 0il Heaters. . . . . . . . . . . . . . 30

12 Comparison Between Isotope and Fuel $0 i 1$ Heaters Based on Equivalent Fuel 0il Price. . . . . . . . . . . . . . 34 
ECONOMIC FEASIBILITY OF STRONTIUM-90

FUELED HEATERS FOR USE IN COLD REGIONS

\subsection{INTRODUCTION}

During the fission process in nuclear reactor operation, radioisotopes, termed fission products, are generated in the reactor fuel. After use in the reactor, the fuel can be reprocessed to recover uranium and plutonium for recycling into fresh nuclear fuel. The remaining fission products and fuel cladding are described as "nuclear waste" since with present technology they cannot be reused in nuclear fuel. However, due to radioactive decay, certain waste fission products have shown potential as heat and irradiation sources; these products could be termed "potential energy resources." The use of radioisotopes as energy sources is considered to be demonstrated technology. Radioisotope heat sources have been used in the past to power such systems as remote weather and navigation aid stations. $(1,2,3)$ Irradiation sources have been used to sterilize food ${ }^{(4)}$ and are currently being studied as a method of sewage treatment. ${ }^{(5)}$

One radioisotope heat source that is presently available from the Department of Energy (DOE) is strontium-90 $\left({ }^{90} \mathrm{Sr}\right)$. This radioisotope is being produced in encapsulated form, and each capsule generates approximately $1 \mathrm{kWt}$. The Division of Advanced Systems and Materials Production of DOE is conducting programs to identify, develop, and demonstrate beneficial applications of waste fission products. Since radioisotope powered systems are highly reliable, require little maintenance, and have long periods between refueling, potential markets for radioisotope systems are remote cold regions, where such qualities in energy systems are highly desirable.

Pacific Northwest Laboratory recently completed a study for DOE to identify potential cold regions applications. ${ }^{(3)}$ One promising application was the use of ${ }^{90} \mathrm{Sr}$ capsules in heating sewage and potable water systems which serve about 50 to 200 people in a remote community. 
The objectives of the present study were to:

- describe the use of radioisotope heat sources,

- conceptually design radioisotope heaters for septic tank and water storage tank applications,

- estimate costs of both radioisotope and fuel oil heaters,

- compare the costs of these two types of systems, and

- make conclusions on the economic feasibility of the radioisotope heaters. 


\subsection{RADIOISOTOPE ENERGY SYSTEMS}

Radioisotope energy systems are powered by the energy released from the decay of a radioisotope. These systems may be designed to provide heat or convert heat to electricity.

\subsection{RADIOISOTOPE HEAT SOURCES}

The principal advantages of using radioisotope heat sources are their high reliability, low maintenance requirements, and long periods between refueling. These advantages compete against the relatively high costs of recovering the radioisotope fuel from the other waste fission products, of encapsulating the fuel material in a metal container, of providing shielding against radiation, and of other factors principally related to the radioactive characteristics of the fuel material.

Due primarily to their radioactivity, radioisotopes can be hazardous. These potential hazards are controlled by the use of external shielding (e.g., lead) to reduce radiation exposure and by providing barriers (e.g., a metal container) against ingestion or inhalation of the radioisotopic material. Since the type of radiation emitted is dependent on the radioisotope, the precautions required may vary significantly. For example, the shielding required for alpha radiation can be provided by a sheet of paper, but for gamma radiation, several feet of concrete or 6 in. of lead may be needed.

The mixture of waste fission products contained in spent nuclear reactor fuel produces all types of radiation; thus, during separation of a specific radioisotope for use as a heat source, the facility must have thick concrete walls and must be built to withstand earthquakes and other natural disasters. Control and maintenance must be done remotely and require special equipment. Once separated, the radioisotope is placed in a high quality metal capsule. The capsule is welded and leak tested. Any radioactive material adhering to the outer walls of the capsule is removed before the capsule is placed in a radioisotope power system. During transport of the fuel capsules either to a power system already on location or in a power 
system being moved to location, radiation shielding must be provided, which can be bulky and heavy. Also, additional weight for structural support may be required to protect the fuel material from entry into the environment in case the transport vehicle is involved in an accident. The above operations and precautions present no technical difficulties; they have been perfected over the past 30 years. However, the elaborate facilities, materials, and operations needed for the radioisotope fuel do significantly increase the costs of these systems.

\subsection{LICENSING REQUIREMENTS}

Since there are potential hazards in using radioactive material, Nuclear Regulatory Commission (NRC) requirements must be met and licenses obtained in order to use a radioisotope powered system. Regulatory Guide 6.3, "Design, Construction, and Use of Radioisotopic Power Generators for Certain Land and Sea Applications" ${ }^{(6)}$ has been issued, which recommends with several additions the International Atomic Energy Agency's Safety Series No. 33. (7) The tests required for the fuel capsule are outlined below:

- a drop test from $9 \mathrm{~m}$

- a percussion test

- thermal test - heated to $800^{\circ} \mathrm{C}$ (or maximum operating temperatures if higher) for 30 minutes

- thermal shock test

- external pressure test $-10^{8}$ newtons ${ }^{2}\left(1.45 \times 10^{4}\right.$ psia $)$

- leakage test $-10^{-8}$ (STP) $\mathrm{cm}^{3} / \mathrm{sec}$

- other tests (e.g., corrosion, creep, irradiation) may be specified. The fuel capsule housing, which is an integral part of the power system, must be tested in a similar manner. If the housing contains the radiation shielding, this shielding must remain intact after each test. If the fuel capsule is transported in a heavy-walled container (transport cask) and placed in the capsule housing on site, the cask must be tested and approved. 
Licensing and a safety assessment report must be completed for the NRC before the heaters can be installed. A license application must designate the radioisotope fuel, intended purpose of device, name and radiation training of individual users of the power systems, radiation experience, radiation detection instruments, facility installation, handling equipment, radiation protection program, and disposal of waste. A safety assessment report requires descriptions of the fuel, fuel capsule, power system, proposed application, accident and hazard analysis, maintenance, responsibility, test program, and ultimate disposal. The length and detail of these reports would be greater for a prototype system than for a design that has been previousiy used.

Transport of radioisotopes is regulated by the Department of Transportation and the Nuclear Regulatory Commission. The radioisotopes must be transported in approved containers. For the quantities of material discussed here, the common name for the container is "transport cask;" the required shielding and structural protection make up a device that would weigh hundreds of pounds. The cask can be part of the energy system, which is usually the case with radioisotope thermoelectric generators, or it can be separate. In the later case, the heat source would be transported to the site, removed from the cask, and inserted into the energy system. The type of cask and the requirements that must be met depend on the transportation mode: rail, sea, truck, or aircraft. Radioisotopes have been transported safely for many years; the design and use of approved shipping casks present no technical difficulties.

\subsection{SYSTEM DESCRIPTIONS}

In general, radioisotope power systems have three common characteristics:

1) a heat source consisting of a radioisotope material enclosed in a metal capsule (heat is generated by the radioactive decay of the isotope);

2) shielding to reduce the external radiation from the heat source; and

3) additional heat transfer and energy converting devices to achieve the desired output: electric, mechanical, or heat. 
The most common type of radioisotope power system that has been developed and used to date is the radioisotope thermoelectric generator (RTG). The RTG is based on the thermoelectric principle that when two dissimilar metals are joined together and heated at the junction, an electrical voltage difference exists between the two free ends. An RTG has a radioisotope source which heats the metal junctions, resulting in an electrical generator that has no moving parts. Energy conversion efficiency of RTGs is approximately $5 \%$. Since the rate of energy production decays with time, the system must be periodically refueled or replaced. The length of time between these operations depends on the specific radioisotope used and on the energy requirements; for strontium-90, a 10-year period can be used as a guideline.

Many RTGs have been built and demonstrated successfully, primarily as remote weather stations and as navigation aids. For example, an RTG has powered a weather station on Fairway Rock in the Bering Strait for over ten years. (See References 1, 2, 3 for more detailed information on other RTG demonstrations.) The Alaskan Region Office, Federal Aviation Administration, installed five RTGs in September 1977 to power aircraft navigation aid systems located in the Lake Clark Pass area between Bristol Bay and Kenai; propane fueled thermoelectric generators were not adequately reliable.

Another type of system which has received increased attention recently due to its higher efficiency $(215 \%)$ involves a radioisotope source heating a working fluid which drives a dynamic electrical generating system. Examples are the Rankine, Brayton, and Sterling Cycle Systems. These systems have not been developed and demonstrated as extensively as RTGs. The dynamic system requires additional operating experience to demonstrate its reliability; the high reliability of the radioisotope heat source is already known from RTG technology.

In the present application of radioisotopes used to heat liquid, the heat source technology (e.g., encapsulating the fuel material and providing radiation shielding) is established technology. However, further experimental work may be needed to determine heat transfer characteristics. 


\subsection{COLD REGION RADIOISOTOPE HEATERS}

Remote cold regions have high fuel oil costs and high system reliability requirements. This has led to the identification of potential applications of radioisotope fueled heaters for sewage and potable water systems.

\subsection{STRONTIUM-90 HEAT SOURCE}

The heat source that is presently available for these heaters is a strontium fluoride $\left(\mathrm{SrF}_{2}\right)$ capsule currently being produced at the Hanford Waste Encapsulation and Storage Facility (WESF), operated for DOE by Rockwell International, Rockwell Hanford Operations. The capsules contain ${ }^{90} \mathrm{Sr}$, which undergoes radioactive decay and in turn, generates heat. The diagram of the $\mathrm{SrF}_{2}$ capsule is shown in Figure 1. (8) This capsule has double containment. The figure also describes the cesium chloride (CSCl) capsule, another WESF product that is less suitable as a heat source. (a) These materials were produced during national defense programs and are being encapsulated for nuclear waste management; presently the capsules are stored in water basins that provide cooling and shielding.

Each $\mathrm{SrF}_{2}$ capsule contains about 150,000 curies of ${ }^{90} \mathrm{Sr}$ (mostly beta decay energy), which generate approximately $1 \mathrm{kWt}$. As the ${ }^{90} \mathrm{Sr}$ decays it decreases with time. The half-1ife of ${ }^{90} \mathrm{Sr}$ is 29 years. Half-1ife is defined as the time required for a sample of a particular radioisotope to decay to only half the original number of atoms of that radioisotope. For example, a sample of pure ${ }^{90} \mathrm{Sr}$ would be $50 \%{ }^{90} \mathrm{Sr}$ and $50 \%{ }^{90} \mathrm{Zr}$ after 29 years (the heat generation rate would drop to approximately $0.9 \mathrm{kWt}$ and $0.8 \mathrm{kWt}$ after 5 and 10 years, respectively.

The Federal Government is presently making its inventory of ${ }^{90} \mathrm{Sr}$ available through the Isotope Sales Division at Oak Ridge National Laboratory, Oak Ridge, Tennessee, at a price of $10 \phi / \mathrm{C} ;{ }^{(9)}$ thus, a WESF capsule

(a) The $\mathrm{CsCl}$ capsule generates about $0.3 \mathrm{kWt}$, primarily from gamma decay energy. Since the $137 \mathrm{Cs}$ gamma radiation penetrates further than the $90 \mathrm{Sr}$ beta radiation and the Cs capsule heat load is about 1/3 the Sr capsule heat load, the $C s$ source has more potential in radiation applications. $(4,5)$ 


\section{WASTE ENCAPSULATION AND STORAGE FACILITY CAPSULE}

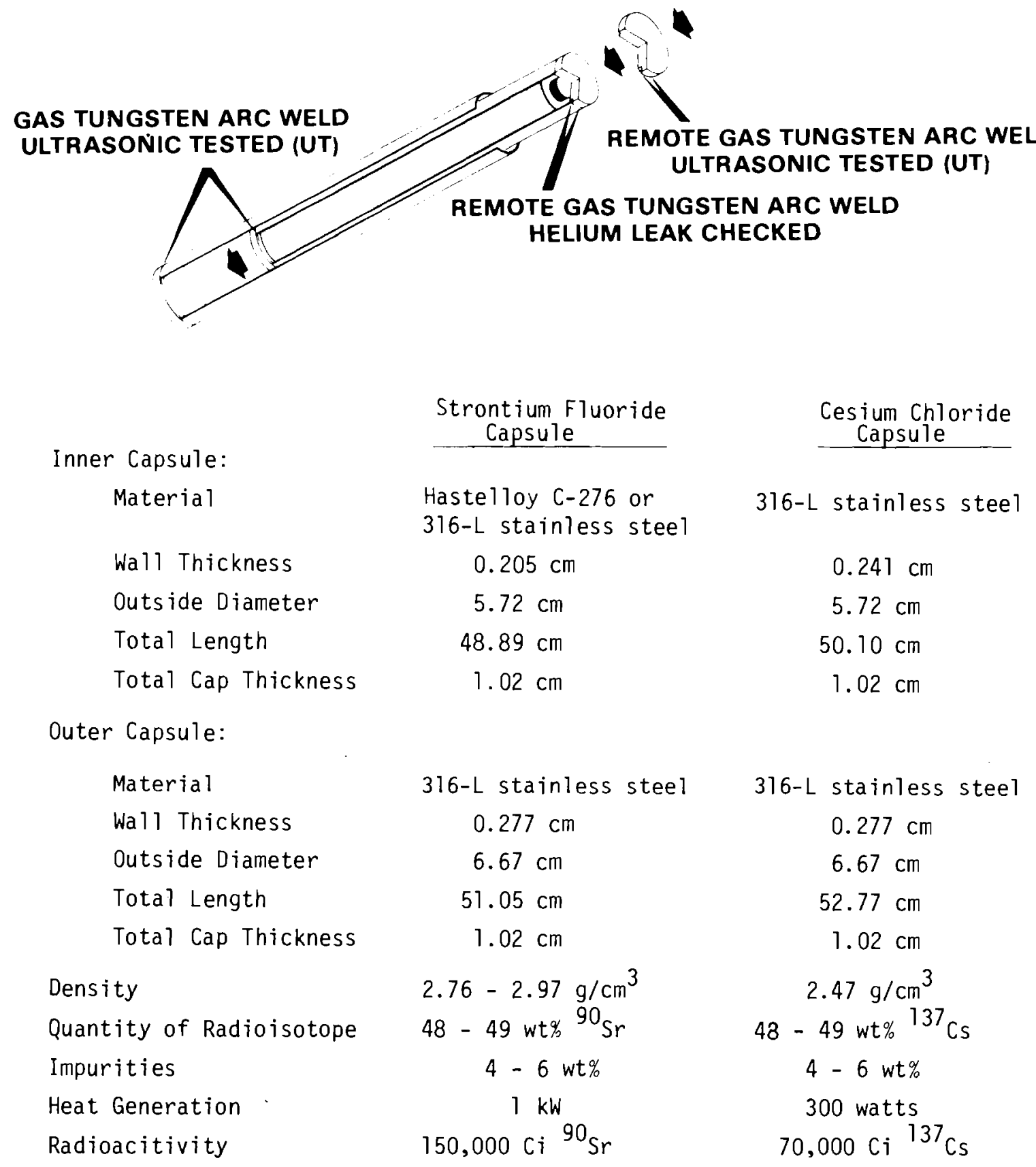

FIGURE 1. WESF Strontium Fluoride and Cesium Chloride Capsule Characteristics 
would cost $\$ 15,000$, excluding incremental handling and shipping charges. There are presently about $200 \mathrm{SrF}_{2}$ capsules on hand. Total production is planned for about 800 capsules.

\subsection{POTENTIAL APPLICATIONS}

Potential applications for radioisotope fueled heaters were identified during discussions with Public Health Service and Environmental Protection Agency staff, who are responsible for designing, building, and maintaining sewage treatment and potable water systems in remote Alaskan communities.

The severe climate and relatively high cost of fuel are the motivating factors for the consideration of radioisotope heaters. These heaters may be economically competitive with other systems because of:

1) high reliability since in extreme cold the failure of a fuel oil system can cause significant damage to equipment;

2) special applications where a radioisotope heater may have reduced capital cost, such as heating an underground septic tank; and

3) a periodic refueling requirement of approximately $10 \mathrm{yr}$.

The problems associated with sewage treatment are caused by low temperatures inhibiting sewage digestion. Tile fields in septic tank systems may need replacement in one or two years because of plugging from solids. The addition of heat to the tank would assist the anaerobic digestion of solids. Heating lagoons would also be beneficial; however, to keep a lagoon from freezing would be extremely costly without insulating the free surface. Keeping small surface areas and transfer structures ice-free might be practical. The Public Health Service roughly estimated that they could use 100 to $2001-k W t$ heaters. Additional applications by others could at least double these numbers. The Federal Aviation Administration has similar sewage treatment problems at some of their remote installations. In general, heating both septic tanks and lagoon systems is considered technically feasible in areas with little or no permafrost. 
Heat requirements for potable water systems are about 100 times greater than for sewage treatment systems, and could be more important in terms of creating a market for radioisotope systems. In many cases, storage tanks are needed for contant potable water supply and must be heated during the winter. The heat requirements vary from month to month. Table 1 gives heat requirements for a 200,000 gal water storage tank located above ground on pilings (a requirement in permafrost areas) and insulated with 4 in. of urethane foam. A radioisotope fueled heater could supply either the total heat requirement or a portion of the requirement (with the remainder supplied by a fuel oil system). Both alternatives will be considered. Another potential use for radioisotope heaters would be to heat a water we11, allowing year-round pumping; this system would be similar to the $1 \mathrm{kWt}$ heaters discussed above.

TABLE 1. Heat Requirements for a 200,000 Gal Water Storage Tank (a)

\begin{tabular}{lccc} 
Month & $\begin{array}{c}\text { Average Air } \\
\text { Temp., }{ }^{\circ} \mathrm{F}\end{array}$ & \multicolumn{2}{c}{ Heat Requirements } \\
\cline { 2 - 3 } Jan & -60 & Btu/hr & kwt \\
Feb & -50 & 40,000 & 11.7 \\
ilar & -30 & 38,000 & 11.1 \\
Apr & -10 & 34,500 & 10.1 \\
ilay & +10 & 30,700 & 9.0 \\
June & +20 & 27,200 & 8.0 \\
July-Sept & +40 or more & 25,400 & 7.4 \\
Oct & +10 & none & none \\
Hov & -10 & 27,200 & 8.0 \\
Jec & -30 & 30,700 & 9.0 \\
Average/Mo & & 34,500 & 10.1
\end{tabular}

Basis: 200 people using $50 \mathrm{gal} /$ person/day

Water inlet temp. $=33^{\circ} \mathrm{F}$, Outlet (Static) $=40^{\circ} \mathrm{F}$

4 in. of urethane foam ( $\left.K=0.11 \frac{\mathrm{Btu}}{\mathrm{hrft}}{ }^{\circ} \mathrm{F} / \mathrm{in}.\right)$

Tank dimensions $=12 \mathrm{ft}$ high, $27 \mathrm{ft}$ radius

(a) This information was provided by L. P. Wallace, Senior Sanitary Engineer, U.S. Public Health Service, Anchorage, Alaska, November 1976. 
Conceptual designs have been developed for the following radioisotope heater systems:

1) $1 \mathrm{kWt}$ self-contained (one WESF capsule) heater which is licensed as a transport cask. No external heat transfer equipment is provided. It is expected that a heater this size could be used to heat a 10,000 gal septic tank which serves a community of about 100 people, lagoon systems, or potable water wells (to allow yearround pumping ).

2) $1 \mathrm{kWt}$ heater which has external heat transfer equipment to enhance heat distribution. The heat source will be transported in a cask, removed from the cask, and inserted into the system. The cask will be reused for fueling other systems. The potential applications are the same as those above.

3) $12 \mathrm{kWt}$ heater without external heat transfer equipment for a 200,000 gallon potable water tank. This will replace an equivalent size fuel oil system.

4) $12 \mathrm{kWt}$ heater with external heat transfer equipment for a potable water tank. The system will be completely built before being fueled with the heat generating capsules.

5) $7 \mathrm{kWt}$ heater without external heat transfer equipment for a potable water tank. Additional peak loads to $12 \mathrm{kWt}$ will be supplied by a back-up $5 \mathrm{kWt}$ fuel oil system.

6) $7 \mathrm{kWt}$ heater with external heat transfer equipment for a potable water tank. A $5 \mathrm{kWt}$ fuel oil system for additional peak loads will also be needed. 


\subsection{ECONOMICS}

The primary economic factors for radioisotope heaters are transportation costs, capital costs for fuel and equipment, installation costs, and minor operating costs. For fuel oil systems the cost factors are for installation, equipment, transportation, fuel 0 il, and maintenance. By comparing total costs for both systems (on capital and annual cost bases), the economic feasibility of each radioisotope system can be determined.

\subsection{TRANSPORTATION OF RADIOISOTOPE FUEL}

For many years radioactive materials have been safely shipped by truck, train, ship, and aircraft. A number of special transportation containers or casks have been designed and used. A review was made of available shipping casks to determine if one existed which could be used to transport a ${ }^{90} \mathrm{Sr}$ WESF capsule by air since this would be the primary method of transport for remote cold region locations. To transport one ${ }^{90} \mathrm{Sr}$ capsule, the container would require shielding equivalent to approximately $7 \mathrm{in}$. of lead $(4 \mathrm{in}$. of uranium) and a $3 \times 24$ in. cavity. No existing casks met the requirements for air (several are available for other transport modes). Recent NRC regulations for licensing air transport casks involve stringent fire and drop tests; thus, it is likely an additional cask would need to be designed and fabricated.

Depending on the design of the heater: 1) the transport cask could be part of the heating system, or 2) the heat sources could be removed from the cask and inserted into the heater system in the field. The first alternative involves less handling of the heat sources when the heater is fueled and refueled, but the capital investment of the heater increases due to the cost of the transport cask. The cask in the second alternative could be used many times to deliver and recover heat sources, and concrete could be used as the heater system shielding. (a) However, a secondary heat

(a) Concrete thickness of $3 \mathrm{ft}$ is approximately equivalent to $0.7 \mathrm{in.} \mathrm{of} \mathrm{lead}$ shielding. Concrete and other materials such as iron are unsuitable as cask shielding for air transport since cask size and weight would be greatly increased. Size and weight are important when considering air transportation charges. 
transfer system may be needed because of the low thermal conductivity and thickness (about $3 \mathrm{ft}$ ) of concrete. Costs will be estimated for both cask al ternatives.

The logistics of transport have alternatives also. It may be more economical to transport three capsules from Hanford to Alaska, then distribute them to three different sites, rather than make a separate delivery for each capsule. A cask containing six or seven capsules could potentially reduce transport costs. Table 2 presents the cask sizes, weights, and costs for lead and uranium shielding. Cost estimates are based on $\$ 4.20 / 1 \mathrm{~b}$ for lead and \$12.60/1b for uranium casks (updated from Ref 10). Lead shielding thickness is $7 \mathrm{in}$. and uranium thickness is 4 in. One in. of stainless steel shell has been included. A stand and cooling fins would add about 250 1b. Uranium has the advantage of being a more effective shielding material than lead, and cask size and weight is reduced for the same cavity size; however, it is more expensive than lead. For a prototype cask, the costs would be much higher for design, safety analysis, and testing. (a)

The transport costs, which can be significant in remote locations, will be based on the following:

- the community is located 260 miles from a major city, such as Fairbanks;

- transport is by fixed wing aircraft; and

- there is either a device in the community or one on the same flight as the cask to handle the cask on the ground.

(a) A range of $\$ 50,000$ to $\$ 100,000$ for the design, safety analysis, and testing of a prototype cask has been estimated. These are one-time costs for a specific design. Since it is assumed one cask design would be used to construct many casks or that one cask would be reused many times, these costs would be distributed to all the systems. For 100 systems, the additional cost would be only $\$ 500$ to $\$ 1,000$. These costs are included in this study in a cask use charge for those situations where one cask is used many times. For the cases where many casks are built from one design (cask as part of heater system), these costs are minor and have not been included. It is recommended that in future analyses if it is known that the number of applications of the cask will be much less than 100, these costs should be included by adding them to those listed in Table 2. 


\section{TABLE 2. Transport Casks}

\begin{tabular}{|c|c|c|c|c|c|}
\hline $\begin{array}{l}\text { No. of } \\
\text { Capsules }\end{array}$ & $\begin{array}{l}\text { Shielding } \\
\text { Material }\end{array}$ & $\begin{array}{l}\text { Cavity } \\
\text { Dimensions, } \\
\text { in. }\end{array}$ & $\begin{array}{l}\text { Overall } \\
\text { Dimensions, } \\
\text { in. }\end{array}$ & $\begin{array}{l}\text { Weight, } \\
\text { lbs. }\end{array}$ & $\begin{array}{l}\text { Cost, } \\
1976 \$ \\
\end{array}$ \\
\hline 1 & Lead & $3 \times 24$ & $19 \times 40$ & 4500 & 20,000 \\
\hline 1 & Uranium & $3 \times 24$ & $13 \times 34$ & 2600 & 33,000 \\
\hline 3 & Lead & $6 \times 24$ & $22 \times 40$ & 5800 & 25,000 \\
\hline 3 & Uranium & $6 \times 24$ & $16 \times 34$ & 3700 & 47,000 \\
\hline 7 & Lead & $9 \times 24$ & $25 \times 40$ & 7200 & 30,000 \\
\hline 7 & Uranium & $9 \times 24$ & $19 \times 34$ & 4800 & 60,000 \\
\hline
\end{tabular}

Once the transport cask is loaded, it must be shipped from Hanford to Fairbanks, then from Fairbanks to the application site. The cask must be returned to Hanford if it is to be reused. Table 3 summarizes estimated transportation charges for two alternatives: 1 ) the cask is part of the heater system, and 2) the cask is reused to fuel many heater systems.

TABLE 3. Costs to Transport Radioisotopes

\begin{tabular}{|c|c|c|c|c|c|c|}
\hline $\begin{array}{l}\text { No. of } \\
\text { Capsules }\end{array}$ & $\begin{array}{l}\text { Shielding } \\
\text { Material }\end{array}$ & $\begin{array}{l}\text { Cask } \\
\text { Wt, Ibs }\end{array}$ & $\begin{array}{l}\text { Transport } \\
\text { Hanford to } \\
\text { Fairbanks, } \\
\quad 1976 \$ \\
\end{array}$ & $\begin{array}{c}\text { Transport } \\
\text { Fairbanks } \\
\text { to Site, } \\
1976 \$ \\
\end{array}$ & $\begin{array}{c}\text { Total Transport } \\
\text { Costs-Cask Part } \\
\text { of Heater, } \\
1976 \$ \\
\end{array}$ & $\begin{array}{c}\text { Total Transport } \\
\text { Costs-Cask Reused } \\
1976 \$ \\
\end{array}$ \\
\hline 1 & $\mathrm{~Pb}$ & 4500 & 800 & 900 & 5200 & 6800 \\
\hline 1 & $U$ & 2600 & 500 & 900 & 4600 & 5600 \\
\hline 3 & $\mathrm{~Pb}$ & 5800 & 1000 & 900 & 5600 & 7600 \\
\hline 3 & u & 3700 & 700 & 900 & 5000 & 6400 \\
\hline 7 & $\mathrm{~Pb}$ & 7200 & 1300 & 900 & 6200 & 8800 \\
\hline 7 & U & 4800 & 900 & 900 & 5400 & 7200 \\
\hline
\end{tabular}

Basis: C-46 Aircraft - 12,000 lb payload, $\$ 3 / a i r$ mile plus $5 \%$ tax and $\$ 100$ loading fee

Truck freight Hanford to Fairbanks $\sim \$ 1 \xi / 100$ lbs. 
Costs are for truck transport to Fairbanks. Air transport costs are based on a C-46 aircraft. It has the advantage of a 12,000 1b payload which allows the crew and materials needed for cask unloading to be transported in the same flight as the cask. It is assumed that ground transport for the cask would be available at the site or could be carried in the $c-46$. (a)

\subsection{RADIOISOTOPE HEATERS}

Potential applications for radioisotope heaters in cold regions are primarily in heating septic tanks, lagoon systems and potable water systems. The thermal output required for septic tanks, lagoon transfer structures, and water wells is $1 \mathrm{kWt}$; for a community water tank, $12 \mathrm{kWt}$ are required. Thus, in this study we are concerned with $1 \mathrm{kWt}$ and $12 \mathrm{kWt}$ radioisotope systems, as well as a $12 \mathrm{kWt}$ combination radioisotope (7 kWt)/fuel oil (5 kWt) system.

The cost estimates for these systems are based on conceptual designs and not on detailed heat transfer analyses. If these radioisotope systems show economic potential, detailed design and cost analysis will be justified. An overall contingency of $20 \%$ is used to account for the absence of detailed design. Detailed design and development costs for the radioisotope systems have been assumed to be one-time costs that would be distributed among many systems and have not been included in the capital cost estimates. Annual capital costs are based on 10\% interest over $10 \mathrm{yr}$, pro-rating these costs over the 10-yr period. (b)

(a) For the uranium cask which weighs 2600 1b, a Twin Otter aircraft (maximum payload 3100 1b) might be used, but the charges would be about the same as for the $\mathrm{C}-46$. If ground transportation is not available at the site or the $\mathrm{C}-46$ cannot carry it, a Hercules aircraft could be used but at a significant cost increase $(45,0001 \mathrm{~b}$ payload at about $\$ 8.50 /$ air mile).

(b) The annual capital cost has been calculated by multiplying the total capital cost by a "capital-recovery factor" (0.163). The capitalrecovery factor is the inverse of the "discrete uniform-series presentworth factors." 


\subsection{1 $1 \mathrm{kWt}$ Heaters}

The first radioisotope heater concept is for a $1 \mathrm{kWt}$ heater that has no external heat transfer equipment; thus, it is essentially a transport cask. Potential applications are for heating septic tanks, lagoon transfer structures, and water wells. Capital costs are for the transport cask, radioisotope fuel, and cask transportation. Operating costs are assumed to be minimal; an inspection each year is probably necessary. This could be done in conjunction with other duties so the costs are distributed. Based on four hours of inspection at $\$ 25 / \mathrm{hr}$ and a distributed living and transportation expense of $\$ 400 /$ trip, total yearly operating costs are estimated to be about $\$ 500$. The cask has lead shielding since the capital cost for a lead cask $(\$ 20,000)$ is less than for a uranium cask (Table 2). The radioisotope fuel costs are $\$ 15,000$. Total transport costs are estimated at $\$ 5200$ (Table 3 ). Table 4 summarizes the costs for this heater concept.

TABLE 4. Preliminary Cost Estimate for $1 \mathrm{kWt}$ Strontium-90 Heater, No External Heat Transfer Equipment

\begin{tabular}{|c|c|c|c|}
\hline Item & & $\cos t$ & $1976 \$$ \\
\hline $\begin{array}{l}\text { Transport Cask (4500 } 1 \\
\text { heater) }\end{array}$ & b lead cask as part of & $\$ 20,000$ & \\
\hline & Equipment Cost Total & & $\$ 20,000$ \\
\hline & $\begin{array}{l}\text { Transportation Cost } \\
\text { Total }\end{array}$ & & 5,200 \\
\hline Radioisotope Fuel (1 9 & ${ }^{10}$ Sr Capsule o $\left.\$ 15,000\right)$ & $\$ 15,000$ & \\
\hline Heater Emplacement and & Recovery (2 workers, & 800 & \\
\hline & $\begin{array}{l}\text { Radioisotope Fuel Cost } \\
\text { Total }\end{array}$ & & 15,800 \\
\hline & Capital Cost Subtotal & & $\$ 41,000$ \\
\hline & Contingency $20 \%$ & & 8,200 \\
\hline & Total Capital Cost & & $\$ 49,200$ \\
\hline & $\begin{array}{l}\text { Annual Capital cost } \\
\text { (10\% interest over } 10 \mathrm{yrs})\end{array}$ & & $\$ 8,000$ \\
\hline & $\begin{array}{l}\text { Annual Operating Cost } \\
\text { (one inspection per year) }\end{array}$ & & 500 \\
\hline & Total Annual Costs & & $\$ 8,500$ \\
\hline
\end{tabular}


The second concept is for a $1 \mathrm{kWt}$ heater that has external heat transfer devices to distribute the heat. A preliminary cost estimate for this system is given in Table 5. The radiation shielding is provided by concrete and the transport cask is reused to fuel many other systems; the objective is to reduce capital costs. A conceptual design of this concept for heating a septic tank is shown in Figure 2 .

TABLE 5. Preliminary Cost Estimate for $1 \mathrm{kWt}$ Strontium-90 Heater, External Heat Transfer Equipment

$\underline{\text { Item }}$

Concrete for Shielding (9 $y d^{3}$ ( $\$ 600 / y d^{3}$ )

2-in. Stainless Steel Pipe $(100 \mathrm{ft}$ a $\$ 40 / \mathrm{ft})$

4-in. Stainless Steel Pipe (20 ft ( $\$ 50 / \mathrm{ft})$

Stainless Steel Shel1 (300 1b o $\$ 3 / 1 b)$

Installation Crew ( 2 workers - 5 days o $\$ 50 / \mathrm{hr}$ )

Equipment Costs Total

Equipment Transportation from Hanford (1,500 1bs)

Installation Crew Transportation (Return to Fairbanks

Cask Use Charge (Cost of 1 cask a $\$ 100,000$ distributed between 100 systems)

Radioisotope Transport (Delivery and Return)

Transportation Costs Tota 1

Radioisotope Fuel ( $1{ }^{90}$ Sr Capsule a $\$ 15,000$ )

Radioisotope Fuel Handling (2 workers - $8 \mathrm{hr}$ o $\$ 50 / \mathrm{hr})$
Cost, $1976 \$$

$$
\begin{array}{r}
\$ 5,400 \\
4,000 \\
1,000 \\
900 \\
4,000 \\
\hline
\end{array}
$$

$\$ 15,300$

$\$ 1,000$

400

1,000

$\underline{5,600}$

8,000

$\$ 15,000$

800

Radioisotope Fuel Total

Capital Cost Subtotal

Contingency 20\%

Total Capital Costs

Annual Capital Cost

(10\% interest over 10 yrs)

Annual Operating cost

(one inspection per yr)

Total Annual Costs
$\$ 7,600$

500

$\underline{15,800}$

$\$ 39,100$

7,800

$\$ 46,900$

$\$ 8,100$ 

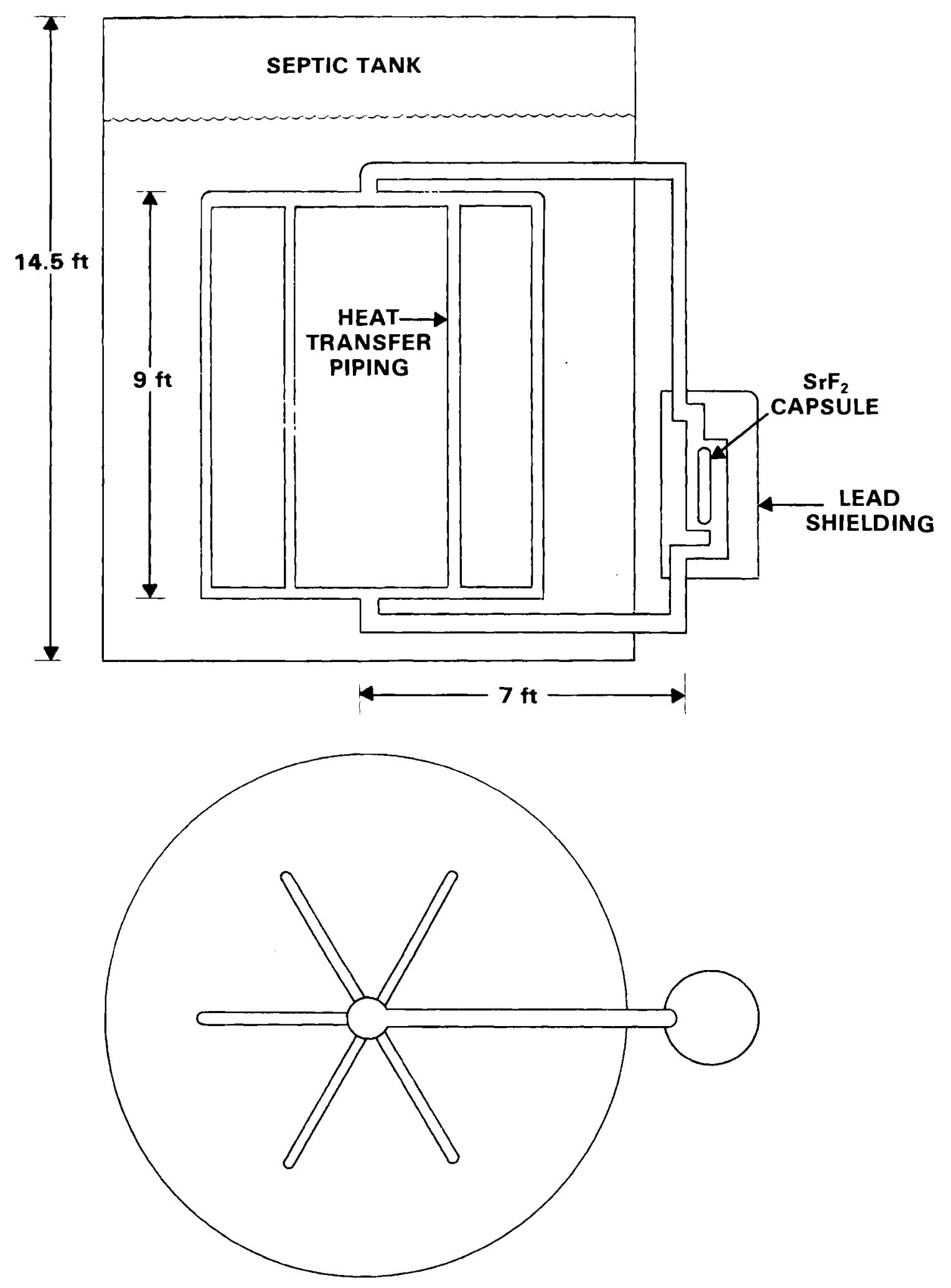

FIGURE 2. Septic Tank Heater - 1 kWt 
The cost estimates in Tables 4 and 5 show that the 1 kWt heater with external heat transfer equipment may have a slight cost advantage over the heater without external equipment. However, the difference in total annual cost of $\$ 8500$ to $\$ 8100$ is not significant, due to the uncertainty of the estimates.

\subsection{2 $12 \mathrm{kWt}$ Heaters}

The cost estimate for a $12 \mathrm{kWt}$ heater that has no external heat transfere equipment is presented in Table 6 . This concept is for two large lead transport casks placed under a 200,000 gal water storage tank. Insulation is added around the lower edge of the tank enclosing the transport casks; thus, heat transfers from the casks up into the water tank. Pilings, a platform, and insulation are needed under the casks to prevent thawing of permafrost. During the warmer months the insulation could be removed or a vent system could be provided to remove excess heat. The total annual cost for this system is estimated at about $\$ 52,000$ per year (over half is the cost of the radioisotopes).

TABLE 6. Preliminary Cost Estimate for a 12 kWt Strontium-90 Water Heater, No External Heat Transfer Equipment

\begin{tabular}{|c|c|c|c|}
\hline \multicolumn{2}{|l|}{ Item } & \multicolumn{2}{|c|}{ Cost, $1976 \$$} \\
\hline \multicolumn{2}{|c|}{ Transport Casks (2 lead casks, 7200 lbs each) } & $\$ 60,000$ & \\
\hline \multicolumn{2}{|c|}{$\begin{array}{l}\text { Housing for Heater (Structure, Insulation, etc. } \\
\quad\left(0 \$ 100 / \mathrm{ft}^{2}, 50 \mathrm{ft}^{2} \text { ) }\right.\end{array}$} & 5,000 & \\
\hline \multicolumn{2}{|r|}{ Equipment Cost Total } & & $\$ 65,000$ \\
\hline \multicolumn{2}{|r|}{ Transport Costs Total } & & 12,400 \\
\hline \multicolumn{2}{|c|}{ Isotope Fuel (12 ${ }^{90} \mathrm{Sr}$ Capsules $@ \$ 15,000$ ea $)$} & $\$ 180,000$ & \\
\hline \multirow{8}{*}{$\begin{array}{l}\text { Heater Emplacement and } \\
16 \text { hrs } Q \$ 50 / \mathrm{hr})\end{array}$} & Recovery (2 workers, & 1,600 & \\
\hline & Isotope Fuel Cost Total & & 181,600 \\
\hline & Capital Cost Subtotal & & $\$ 259,000$ \\
\hline & Contingency $20 \%$ & & 51,800 \\
\hline & Total Capital Cost & & $\$ 310,800$ \\
\hline & $\begin{array}{l}\text { Annual Capital Cost } \\
\text { (10\% interest over } 10 \mathrm{yrs})\end{array}$ & & $\$ 50,700$ \\
\hline & $\begin{array}{l}\text { Annual Operating Cost } \\
\text { (One inspection per yr plus } \\
\text { manual control of heat) }\end{array}$ & & 1,000 \\
\hline & Total Annual Costs & & $\$ 51,700$ \\
\hline
\end{tabular}


A 12 kWt water tank heater with heat transfer equipment is shown in Figure 3. The primary components are concrete shielding (about $3 \mathrm{ft}$ thick), the secondary barrier (stainless steel pipe) between the capsule and water, and piping for water transport. There is an air gap between the capsule and secondary barrier, with a drain at the bottom of the gap; thus, if a leak develops in the barrier, any water that might contact the capsule would flow out of the system. This water would become contaminated with strontium-90 only if the double capsule walls, the primary barriers, were breached. Therefore, this design ensures that no strontium-90 could enter the potable water system. This concept assumes natural circulation of the water. The capsules are transported in a cask, then loaded into the system. The preliminary cost estimate for this heater concept is given in Table 7. Several modes of capsules transport were considered: 1 capsule per cask, 3 capsules per cask, and 7 capsules per cask. The costs of these various options can be compared by referring to Table 3; the reuse of the 7 capsule cask is the most cost-effective.

In comparing the two types of $12 \mathrm{kWt}$ heaters, once again the system with the external heat transfer equipment has a lower annual cost estimate $(\$ 44,000)$ than the system consisting of two lead transport casks $(\$ 52,000)$. This is primarily due to the higher estimated cost of the transport casks compared to the concrete shielded heat transfer system. However, several assumptions have been made for the latter system which, if varied, could significantly increase costs. The costs of concrete are based on four times Hanford costs, assuming it is fabricated in the field. Pipe costs have been estimated based on Hanford costs plus field labor and transportation since piping could be pre-fabricated then assembled on location.

\subsubsection{2 kWt Combination Radioisotope/Fuel $0 i 1$ Systems}

The last two concepts are water tank heaters consisting of a $7 \mathrm{kWt}$ isotope heater with a secondary $5 \mathrm{kWt}$ fuel $0 i 1$ system to supply additional power during winter peak loads (the $5 \mathrm{kWt}$ system costs are developed in the following section). The radioisotope heater with no external heat transfer equipment is compared to one with external heat transfer equipment. The 


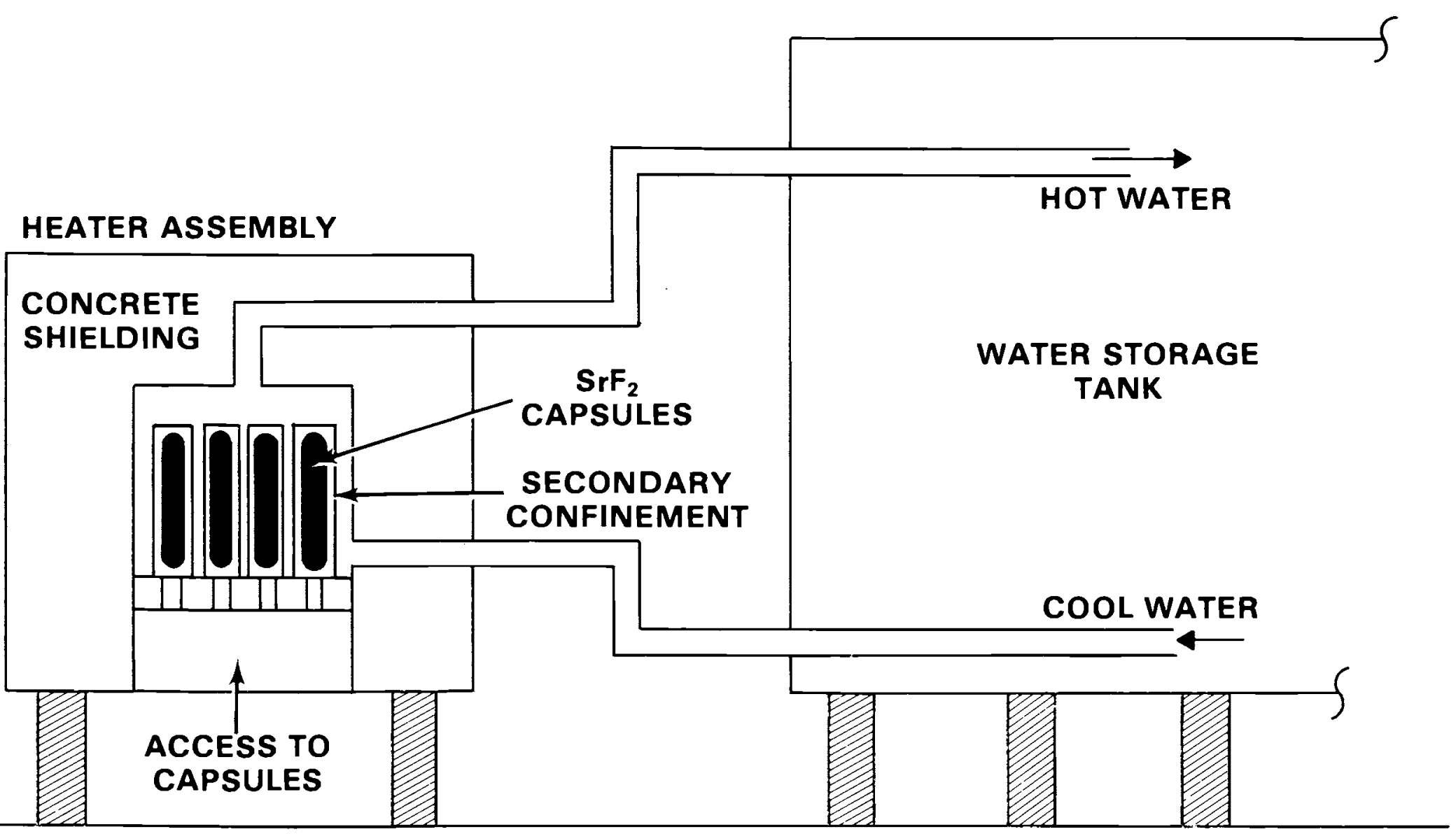

FIGURE 3. Water Storage Heater - $12 \mathrm{kWt}$ 
TABLE 7. Preliminary Cost Estimate for a $12 \mathrm{kWt}$ Strontium-90 Water Heater, External Heat Transfer Equipment

$\underline{\text { Item }}$

Cost, $1976 \$$

Concrete for Shielding (13 yd $\mathrm{yd}^{3}$ e $\left.\$ 600 \mathrm{yd}^{3}\right)$

$\$ 8,000$

Stainless Steel (Secondary barriers, cavity lines, 5,000 etc. fabricated at Hanford)

$2-i n$. Stainless Steel (50 ft a $\$ 50 / f t$ ) Pipe 2,500

Installation Crew ( 3 workers - 5 days $8 \$ 50 / h r$ )

$\underline{6,000}$

Equipment Costs Total

$\$ 21,500$

Equipment Transportation from Hanford (about 2,000 1b)

Installation Crew Transportation (Return to Fairbanks)

Cask Use Charge (Cost of Cask o \$150,000

Distributed between 100 systems

Radioisotope Transport (Delivery and Return

$\underline{14,400}$

Transportation Costs Total

$\$ 1,000$

400

Radioisotope Fuel ( $12{ }^{90} \mathrm{Sr}$ Capsules a $\$ 15,000$ ea) $\$ 180,000$

Radioisotope Fuel Handling (2 workers $-24 \mathrm{hr}$ ( $\$ 50 / \mathrm{hr}$ ) 2,400

Radioisotope Fuel Total

$\underline{182,400}$

Capital Cost Subtotal

$\$ 221,200$

Contingency $20 \%$

44,200

Total Capital Costs

$\$ 265,400$

Annual Capital Cost

$\$ 43,300$

(10\% interest over $10 \mathrm{yr}$ )

500

Annual Operating Costs

(one inspection per yr)

Total Annual Costs

$\$ \underline{43,800}$ 
costs for the $7 \mathrm{kWt}$ radioisotope portion of these combination systems are presented in Tables 8 and 9, respectively. The annual costs are somewhat higher for the self-contained heater $(\$ 29,000$ compared to $\$ 27,000)$, as in the previous cases.

TABLE 8. Preliminary Cost Estimate for a $7 \mathrm{kWt}$ Strontium-90 Water Heater, No External Heat Transfer Equipment

$\underline{\text { Item }}$

Transport Cask (1 lead cask, 7200 1b)

Housing for Heater

Equipment Cost Total

Transportation Cost Total

Radioisotope Fuel ( $7{ }^{90} \mathrm{Sr}$ Capsules @ $\$ 15,000$ ea) Heater Emplacement and Recovery (2 workers -

$12 \mathrm{hr}$ o $\$ 50 / \mathrm{hr}$ )

\begin{tabular}{|c|c|}
\hline \multicolumn{2}{|l|}{$\$ 30,000$} \\
\hline \multicolumn{2}{|l|}{3,000} \\
\hline & $\$ 33,000$ \\
\hline & 6,200 \\
\hline \multicolumn{2}{|l|}{$\$ 105,000$} \\
\hline \multicolumn{2}{|l|}{1,200} \\
\hline & $\$ 106,200$ \\
\hline & 145,400 \\
\hline & 29,100 \\
\hline & $\$ 174,500$ \\
\hline & $\$ 28,400$ \\
\hline & 1,000 \\
\hline & $\$ 29,400$ \\
\hline
\end{tabular}

$\begin{array}{lr}\text { Radioisotope Fuel Cost. Total } & \$ 106,200 \\ \text { Capital Cost Subtotal } & 145,400 \\ \text { Contingency 20\% } & \underline{\$ 17,100} \\ \text { Total Capital Cost } & \$ 28,400 \\ \text { Annual Capital Cost } & \\ \text { (10\% interest over 10 yr) } & 1,000 \\ \text { Annual Operating Cost } & \$ 29,400 \\ \text { Total Annual Cost } & \end{array}$


TABLE 9. Preliminary Cost Estimate for a $7 \mathrm{kWt}$ Strontium-90 Water Heater, External Heat Transfer Equipment

\section{$\underline{\text { Item }}$}

Concrete for Shielding (11 $\mathrm{yd}^{3}$ a $\$ 600 / \mathrm{yd}^{3}$ )

Stainless Steel (Secondary barriers, cavity liner, etc. fabricated at Hanford)

2-in. Stainless Steel Pipe (50 ft a $\$ 50 / \mathrm{ft}$ )

Installation Crew ( 3 workers -5 days $0 \$ 50 / \mathrm{hr}$ )

Equipment Cost Total

Equipment Transportation from Hanford (about 7,000 1b)

Installation Crew Transportation (Return to Fairbanks)

Cask Use Charge (Cost of cask @ \$150,000 distributed between 100 systems)

Radioisotope Transport (Delivery and Return)

Transportation Costs Total

Radisotope Fuel ( $7{ }^{90}$ Sr Capsules a $\$ 15,000$ ea)

Radioisotope Fuel Handling (2 workers - $16 \mathrm{hr}$ (a) $\$ 50 / \mathrm{hr}$ )
Cost, $1976 \$$

$\$ 6,600$

4,000

2,500

$\underline{6,000}$

$\$ 19,100$

$\$ 1,000$

400

1,500

7,200

10,100

$\$ 105,000$

1,600

Radioisotope Fuel Total

$\underline{106,600}$

Capital Cost Subtotal

$\$ 135,800$

Contingency $20 \%$

27,200

Total Capital Costs

$\$ 163,000$

Annual Capital Costs

(10\% interest over $10 \mathrm{yr}$ )

$\$ 26,600$

Annual Operating Costs

500

(One inspection per $y r$ )

Total Annual Costs

$\$ 27,100$ 
Two basic radioisotope systems have been discussed: self-contained units (transport casks) and concrete shielded power units with external heat transfer equipment. The latter systems appear to be slightly less costly than the self-contained units, at least from the cost estimate assumptions used here. However, the self-contained units have several advantages which could make them more economical: 1) licensing could be simpler since an air transport cask would probably be designed to withstand more severe conditions than would be required for a radioisotope heater, and 2) handling of capsules at the site would be minimized (they remain in the transport cask). An advantage of the units with external heat transfer equipment is that in certain applications they distribute heat more efficiently and economically.

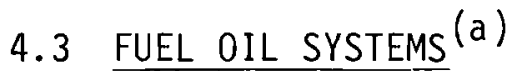

The smallest fuel oil boiler available in Anchorage, Alaska, has a maximum output of $23 \mathrm{kWt}(80,000 \mathrm{BTU} / \mathrm{hr})$ and consumes about $1 \mathrm{gal}$ fuel $011 / \mathrm{hr}$. The cost estimates for fue 1 oil heaters located in remote Alaskan communities are based on this boiler. Four modes of operation are considered:

1) heating a potable water tank (200,000 ga 1$)$, maximum requirement during the coldest weather is $12 \mathrm{kWt}$;

2) heating a potable water tank in conjunction with a 7 kWt radioisotope heater, maximum output is $5 \mathrm{kWt}$;

3) heating a septic tank or other equipment that has continuous heat requirement ( $1 \mathrm{kWt})$; and

4) heating both a potable water tank and a septic tank, maximum output is $13 \mathrm{kWt}$.

Since $13 \mathrm{kWt}$ is the maximum output needed, the $23 \mathrm{kWt}$ boiler is underutilized by at least $10 \mathrm{kWt}$.

(a) The costs for fuel oil systems have been extrapolated from information supplied by engineers who have experience with these types of systems: L. P. Wallace, Senior Sanitary Engineer, U.S. Public Health Service, Alaska Area Native Health Service, Anchorage Alaska, and B. H. Reid, Research Engineer, Environmental Protection Agency, Artic Environmental Research Laboratory, College, Alaska, November 1976. 


\subsection{1 $12 \mathrm{kWt}$ Heaters}

One method of heating a potable water tank is to operate the $23 \mathrm{kWt}$ capacity boiler at a $12 \mathrm{kWt}$ level. The fuel oil consumption is $3200 \mathrm{gal} / \mathrm{yr}$, based on heat load information in Table 1 (Section 3.2) with slight additions for heating the boiler building. Table 10 outlines the estimated cost of this system. Total capital cost is $\$ 9700$ and the total annual cost, including fuel oil at $\$ 1.50 /$ gal, is $\$ 10,300$.

TABLE 10. Cost Estimate for a $12 \mathrm{kWt}$ Fuel $0 i 1$ Water Tank Heater

\begin{tabular}{|c|c|c|c|}
\hline Item & & $\cos$ & $1976 \$$ \\
\hline Boiler & & $\$ 7,000$ & \\
\hline Heat Exchanger & & 300 & \\
\hline Piping & & 200 & \\
\hline Electrical & & 100 & \\
\hline Installation & & $\underline{1,000}$ & \\
\hline & Boiler Equipment Costs Subtotal & $\$ 2,600$ & \\
\hline Building & & $\$ 4,500$ & \\
\hline Site Preparation & & 100 & \\
\hline Electrical & & 200 & \\
\hline Miscellaneous & & $\underline{200}$ & \\
\hline & Building Cost Subtotal & $\$ \underline{5,000}$ & \\
\hline & Equipment Cost Total & & $\$ 7,600$ \\
\hline & Transportation Cost Total & & 1,200 \\
\hline & Capital Cost Subtotal & & 8,800 \\
\hline & Contingency $10 \%$ & & 900 \\
\hline & Total Capital Cost & & $\$ 9,700$ \\
\hline & $\begin{array}{l}\text { Annual Capital Cost } \\
(10 \% \text { interest over } 10 \text { yrs })\end{array}$ & & $\$ 1,600$ \\
\hline & Annual Labor & & 1,800 \\
\hline & Annual Inspection and Repairs & & 1,600 \\
\hline & Electricity & & 500 \\
\hline & Fuel $0 \mathrm{il} @ \$ 1.50$ (3200 gal) & & $\underline{4,800}$ \\
\hline & Total Annual Cost & & $\$ 10,300$ \\
\hline
\end{tabular}


An alternative to using a $12 \mathrm{kWt}$ system produced solely by fuel oil is to supplement the fuel oil heater with a radioisotope heater. A $5 \mathrm{kwt}$ fuel oil heater in conjunction with a $7 \mathrm{kWt}$ radioisotope heater was considered as such an alternative. For a $5 \mathrm{kWt}$ fuel oil system, the capital cost is the same as the $12 \mathrm{kWt}$ system, $\$ 9700$ (both systems use the $23 \mathrm{kWt}$ boiler). Annual operating costs would be reduced, since $5 \mathrm{kWt}$ (needed only in coldest periods, see Table 1) would only use $800 \mathrm{gal}$ of fuel oil a year. The savings of $\$ 3600$ would result in a total annual cost of $\$ 6700 / y$ r. Costs of a $7 \mathrm{kWt}$ radioisotope system have to be included in this alternative, and significantly effect the estimate (Tables 8 and 9 ).

\subsubsection{I kWt Heaters}

It is estimated that only $1 \mathrm{kWt}$ of power is required to heat the septic tank. (a) This can be accomplished in two ways: 1) by running the 23 kWt boiler periodically, having the same effect as a 1 kWt heater running continuously, or 2 ) by using the same boiler as the water tank heater by increasing the output from $12 \mathrm{kWt}$ to $13 \mathrm{kWt}$.

The first option is the least efficient and the most expensive. Such an option would only be considered if the septic tank is isolated and no other heat sources are feasible. The total capital cost would again be $\$ 9700$. The fuel oil requirement would be $400 \mathrm{gal} / \mathrm{yr}$, saving $\$ 4200 / \mathrm{yr}$ from the $12 \mathrm{kWt}$ fuel costs. Total annual costs for this system would be $\$ 6100$.

The second option for heating a septic tank is far more cost effective than the first, but is dependent on a community having the need for both $12 \mathrm{kWt}$ and $1 \mathrm{kWt}$ heaters. It involves piping steam from a boiler house to a heat exchanger in the septic tank. In this case, costs for the $13 \mathrm{kWt}$ system (12 kWt for water heater $+1 \mathrm{kWt}$ for the septic tank) are distributed to the $1 \mathrm{kWt}$ system by a factor of $1 / 13$ (excluding costs for additional piping, heat exchanger and fue 1 oil). Assuming a distance of $50 \mathrm{ft}$ between the boiler house and the septic tank, the capital cost for the $1 \mathrm{kWt}$

(a) Other equipment such as lagoon transfer structures and water wells could also use $1 \mathrm{kWt}$ for more efficient operation. A septic tank is used here only as an example. 
portion of the system is $\$ 3800$ (including two separate pipes at $\$ 25 / \mathrm{ft}$ and a heat exchanger at $\$ 500$ ). The fuel oil consumption is about $480 \mathrm{gal} / \mathrm{yr}$ since some heat is Tost during transport through the pipes. Thus, the total annual cost is $\$ 1600 / y r$.

If full use could be made of the $23 \mathrm{kWt}$ capacity boiler, costs could be distributed in all the systems, making each more cost effective. One possible additional application is the heating of homes; however most dwellings are located more than $50 \mathrm{ft}$ from the boiler, so it is probably more cost effective to have separate home heaters. In this study, it will be assumed that the 5 and $12 \mathrm{kWt}$ fuel $0 i 1$ systems do not have distributed costs; a $1 \mathrm{kWt}$ system would more likely have distributed costs.

\subsection{ECONOMIC COMPARISONS}

When comparing radioisotope and fuel oil systems, the reliability of the radioisotope systems can offer significant cost savings. This is one of the prime motivating factors for the Federal Aviation Administration's interest in using radioisotope thermoelectric generators to power remote aircraft navigational aid systems. The reliability of fuel oil systems varies with complexity of the system and the conditions of system failure. One rough estimate was that one or two systems must be replaced each year out of a total of 60 to 70 systems. The freezing and subsequent destruction of equipment, and accidental damage during attempts to restart or repair systems are reasons for system replacement. To account for this reliability, a factor of 2/60 (0.033) will be added to the annual capital cost of each fuel oil system. Thus, 60 systems are charged for the 2 systems that fail each year. The annual cost is $\$ 300$ for each 12 and $5 \mathrm{kwt}$ system and from $\$ 100$ to $\$ 300$ for a $1 \mathrm{kWt}$ system.

Table 11 summarizes the costs for both radioisotope and fuel oil systems. In every case, the capital investment required for radioisotope systems is high when compared to the fuel oil system. However, since the radioisotope systems do not consume fuel oil, which is an operating cost, it is more appropriate to compare the two types of systems based on total annual cost, 
TABLE 11. Comparison Between Total Capital and Annual Costs of Radioisotope and Fuel 0il Heaters

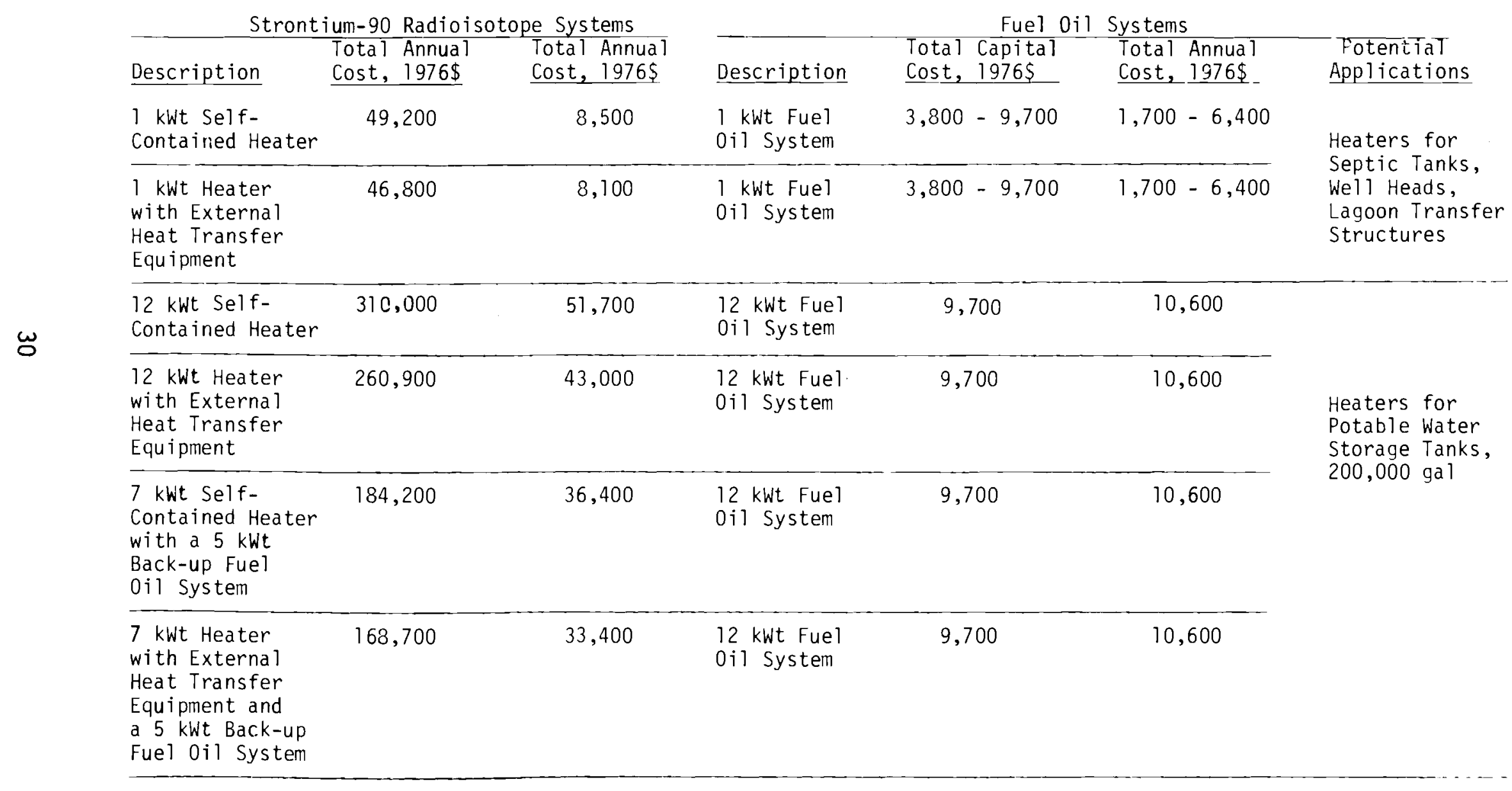


which includes both annual capital and operating charges. Again the radioisotope systems are more costly, but the ratios are lower. Apparently, there is a slight advantage of a $7 \mathrm{kWt}$ radioisotope heater combined with a $5 \mathrm{kWt}$ fuel oil system over a $12 \mathrm{kWt}$ radioisotope heater. The combination system has annual costs 3 to 4 times higher than a $12 \mathrm{kWt}$ fuel oil system; the $12 \mathrm{kWt}$ radioisotope system's annual costs are 4 to 5 times higher.

For the 1 kWt heater, the radioisotope systems appear to approach the upper annual cost range of the fuel oil systems. However, it must be noted that this upper range is for a $23 \mathrm{kWt}$ boiler totally dedicated to delivering $1 \mathrm{kWt}$. This could only occur: 1) if there were no other 23 kWt fuel oil boilers in the community which could supply 1 kWt so that a separate boiler was required, or 2) if piping costs to span the distance between an existing $23 \mathrm{kWt}$ boiler and the $1 \mathrm{kWt}$ were large enough to justify a separate system (approximate limit on piping distance is $600 \mathrm{ft}$, not including energy loss for transport of steam and condensate.

One cost that has not been included for the radioisotope systems is for licensing - completing a license application and safety assessment report. For the first prototype system the costs would be significant, but for additional applications of the same system the costs would be reduced since much of the information contained in the first safety assessment would apply to the additional applications (see Section 2.2). It is estimated that these ricensing activities would cost $\$ 2,000$ to $\$ 5,000$ per application. These costs would be somewhat offset by fuel $0 i 1$ system design costs which are also not included. The fuel oil system costs could run about the same order of magnitude as the isotope system licensing costs. Thus, the impact of not including these costs on the results in Table 11 is minor. Radioisotope system development costs are also not included. These are assumed to be a one-time cost distributed among many systems.

The results in Table 11 are based on a fuel oil price of $\$ 1.50 /$ gal. Since these prices depend on location and are increasing at a potentialiy higher rate than equipment and other costs, radioisotope systems could become more economically competitive in the future. One method of 
analyzing various costs is to consider the costs on the basis of an equivalent fuel oil price:

- equating annual radioisotope system and fuel oil costs;

- factoring out the annual fuel oil quantity requirement; and

- dividing by the requirement.

The following equation further describes this method. For radioisotope system costs to equal fuel oil system costs:

Annual Cost of Radioisotope System = Annual Cost of Fuel $0 i 1$ System

(Annual Capital Cost + Annual Operating Cost) Radioisotope Sysiem

$$
\int=\left\{\begin{array}{l}
\text { (Annual Capital Cost }+ \text { Annual } \\
\text { Operating Cost) Fuel } 0 i 1 \\
\text { System }
\end{array}\right.
$$

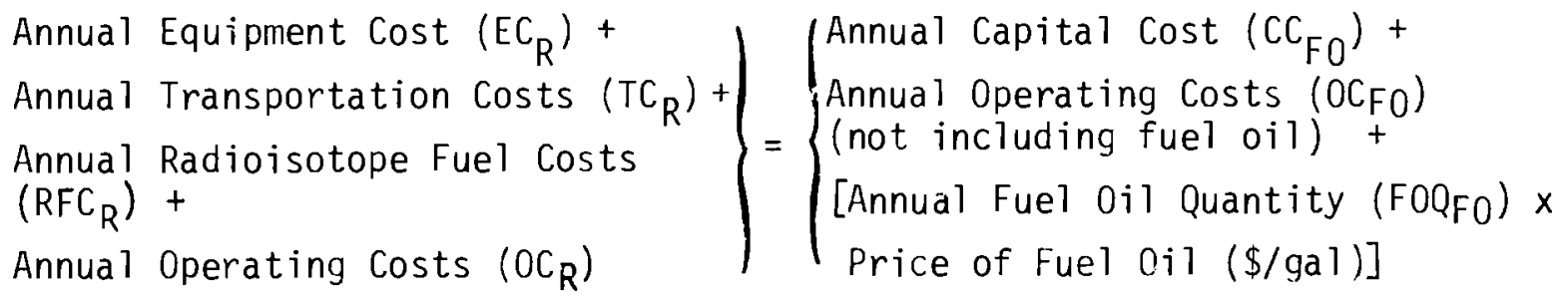

$$
E C_{R}+T C_{R}+R F C_{R}+O C_{R}=C C_{F 0}+O C_{F O}+\left(F O Q_{F 0} \times \$ / g a 1\right)
$$

Rearranging:

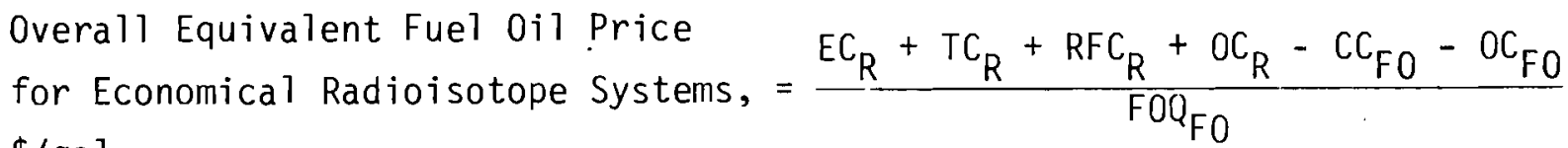
$\$ /$ gal

Thus, overall equivalent fuel oil price is the price of fuel oil that would make radioisotope systems economically competitive with fuel oil systems; any fuel oil price higher than this value indicates that radioisotope systems are more cost effective. The right side of the above equation allows various costs to be factored out in terms of equivalent fuel oil price. 
Table 12 gives equivalent fuel oil prices for each alternative radioisotope system. Contingency has been distributed among the various costs. On this basis, the price of fuel $0 i 1$ which presently can vary from $\$ 1.00$ to $\$ 2.00 / \mathrm{ga} 1$ ( $\$ 1.50 \mathrm{gal}$ seems to be a representative value in remote communities) would have to increase to at least $\$ 7.00 /$ gal or as high as $\$ 16.00 /$ gal for radioisotope heaters to compete economically with fuel oil systems. Based on $10 \%$ inflation each year for $10 \mathrm{yr}$ and an initial fuel oil price of $\$ 1.50 / \mathrm{gal}$, the effective average fuel oil price over the full $10 \mathrm{yr}$ is $\$ 2.40 / g a 1$. Thus, radioisotope systems are not economical.

About one-half the major costs for the $1 \mathrm{kWt}$ radioisotope systems are for equipment. Equipment costs in Table 12 are based on a 10-yr life. If the equipment 1 ife could be extended to $20 \mathrm{yr}$ (10\% interest over $20 \mathrm{yr}$ ), the annual costs would be reduced. The most likely application would be the self-contained unit which could possibly be returned, refueled, and used as a heater for another $10 \mathrm{yr}$. If this occurred, equipment costs would be reduced to between $\$ 5.84$ and $\$ 7.57 /$ gal and overall equivalent fuel oil price would decrease to a range of $\$ 13.54$ to $\$ 5.14 /$ gal. These costs are still much too high for economic application. The 20-yr evaluation could be applied to the other self-contained $12 \mathrm{kWt}$ and $7 \mathrm{kWt}$ systems, but the cost reduction would be less since the equipment costs make up a smaller fraction of the total. Another problem with 20-yr systems is that a reasonably priced supply of heat generating material to refuel the heaters after $10 \mathrm{yr}$ is not certain at this time.

The other major cost factor to consider in radioisotope systems is fuel based on 10 $\$$ /curie, which is the official Federal Government price. The question arises: if capsules of strontium are produced for nuclear waste management reasons and if they are not used beneficially because the price is too high, why not supply these capsules at no cost and at least gain some benefit by saving fuel oil? If this were to occur, the overall equivalent fuel oil price of the $1 \mathrm{kWt}$ heaters could drop below $\$ 2.40 / \mathrm{gal}$ (or even $\$ 1.50 /$ gal) for certain applications, where the distance from the existing $23 \mathrm{kWt}$ system is large or a $23 \mathrm{kWt}$ boiler is totally dedicated to a $1 \mathrm{kWt}$ requirement. Also, the overa 11 costs for a $12 \mathrm{kWt}$ radioisotope 
TABLE 12. Comparison Between Radioisotope and Fuel 0 il Heaters Based on Equivalent Fuel 0 il Price

\begin{tabular}{|c|c|c|c|c|c|c|c|c|}
\hline \multirow{2}{*}{$\begin{array}{l}\text { Isotope Systeal } \\
\text { Description }\end{array}$} & \multicolumn{4}{|c|}{ Radioisotope System Annual Costs, S/gal } & \multicolumn{2}{|c|}{$\begin{array}{l}\text { Fuel } 0 \text { is System Annual } \\
\text { Costs, \$iga? }\end{array}$} & $\begin{array}{l}\text { Overu?: } \\
\text { Equivalent }\end{array}$ & \multirow[t]{2}{*}{ Potential Applications } \\
\hline & Equipment & $\begin{array}{l}\text { Transpor- } \\
\text { tation }\end{array}$ & $\begin{array}{l}\text { Radioisotope } \\
\text { Fuel }(c)\end{array}$ & Operating & Capital & operating & $\begin{array}{l}\text { Fuel } 0 i 1 \\
\text { F'ice } \\
\text { S/yal (b) }\end{array}$ & \\
\hline $\begin{array}{l}1 \text { kWt Self- } \\
\text { Contained Heater }\end{array}$ & $8.13-10.54$ & $2.08-2.70$ & $6.46-8.38$ & $1.04-1.35$ & $1.25-4.32$ & $0.63-10.54$ & $15.33-8.11$ & \multirow{2}{*}{$\begin{array}{l}\text { itcelters for Septic Tanks, } \\
\text { Well Hcads, Lagoon Transfer } \\
\text { Structures }\end{array}$} \\
\hline $\begin{array}{l}\text { kwt Heater with } \\
\text { External Heat } \\
\text { Transfer Equip- } \\
\text { ment }\end{array}$ & $6.25-8.11$ & $3.13-4.05$ & $6.46-8.38$ & $1.04-1.35$ & $1.25-4.32$ & $0.63-10.54$ & $15.00-7.04$ & \\
\hline $\begin{array}{l}12 \mathrm{kWt} \text { Self- } \\
\text { Contalner Heater }\end{array}$ & 3.97 & 0.75 & 17.13 & 0.31 & 0.50 & 1.22 & 14.44 & \multirow{4}{*}{$\begin{array}{l}\text { Heaters for Potable Water } \\
\text { Storage Tanks }-200,000 \text { gal }\end{array}$} \\
\hline $\begin{array}{l}12 \mathrm{kWt} \text {. Heater with } \\
\text { Externàl Heat } \\
\text { Transfer Equip- } \\
\text { ment }\end{array}$ & 1.31 & 1.06 & 11.16 & 0.16 & J. 50 & 1.22 & 11.97 & \\
\hline 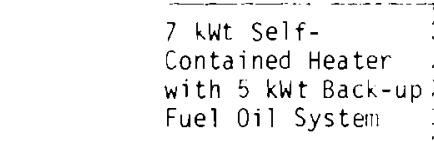 & 2.96 & 0.50 & 3.63 & 2.04 & 0.67 & 1.63 & 11.33 & \\
\hline $\begin{array}{l}7 \text { kwt Heater with } \\
\text { External Heat } \\
\text { Transfer Equip- } \\
\text { ment with } 5 \text { kwt } \\
\text { Back-up Fuel 0il } \\
\text { Systent }\end{array}$ & 2.21 & 0.82 & 8.71 & 1.83 & 0.67 & 1.63 & 11.28 & \\
\hline
\end{tabular}
(a) Excluding fuel oil costs
(b) Overall Equivalent Fuel 0il Price = Radioisotope System Annual Cost - Fuel 0il System Annual cost
(c) Based on $10 \notin / \mathrm{Ci}^{90} \mathrm{Sr}$ 
heater with external heat transfer equipment combined with a $5 \mathrm{kWt}$ back-up fuel oil system could decrease to about $\$ 2.50 /$ gal . However advantageous a strontium price reduction to zero appears, the following factors should be considered:

1) the present supply of Hanford's Waste Encapsulation and Storage Facility (WESF) strontium-90 capsules is limited. Current projections are for a maximum of 800 capsules which would supply about 67 12-kWt or 800 1-kWt radioisotope heaters;

2) a portion of the presently available strontium capsules would be needed for more cost effective applications which, in general, would be specialty uses where other types of systems are unsatisfactory from a reliability standpoint, e.g., space applications, navigation aids such as aircraft or submarine, and communications systems;

3) one of the objectives of current nuclear waste programs is to develop large scale applications which would economically justify private industry to construct and operate a nuclear waste fission recovery plant. If private industry were to recover strontium on a large scale, it is likely that prices would be higher than $10 \$$ /curie. Therefore, once the zero cost strontium supply is consumed, radioisotope fuel resupply costs for existing heaters and initial fuel costs for the new radioisotope heaters would increase even above the costs presented in Tables 11 and 12 .

The likelihood of a strontium price reduction is uncertain at this time. This decision must be made by various government agencies which are in charge of the radioisotopes and potential user agencies or potential private users. 


\subsection{CONCLUSIONS}

The use of strontium-90 heat sources to fuel cold region radioisotope heaters does not appear to be an economically feasible venture, at least based on a price of $10 \$ /$ curie. Various factors which would make radioisotope heaters more economically competitive are:

1) a price reduction to below $10 \$ /$ curie,

2) a dramatic increase in fuel oil prices, and

3) a decision that fuel oil system reliability or adaptability is not satisfactory and radioisotope systems would be satisfactory.

It is recommended that these heaters not be considered further unless at least one of the preceding factors occurs. The costs of radioisotope heaters are so high that it would probably take a combination of these factors to make cold regions radioisotope heaters economically feasible. 
$-$

' 


\section{REFERENCES}

1. W. R. Corliss and D. G. Hawey, Radioisotopic Power Generation. Prentice-Hal1, Inc., Englewood, NJ, 1964.

2. R. P. Cope and T. P. Fleming, "U.S. Navy Radioisotope Power Generator Program." Isotopes and Radiation Technology 9(3):323-329, 1972.

3. L. D. Perrigo, Cold Regions Isotope Applications. BNWL-1935, Battel le, Pacific Northwest Laboratories, Richland, WA, 99352, Apri1 1976.

4. International Atomic Energy Agency and the Food and Agriculture Organization of the United Nations, Radiation Preservation of Food, Proceedings of a Symposium held in Bombay, November 13-17, 1972, International Atomic Energy Agency, Vienna, 1973.

5. W. C. Remini, E. J. Wahlquist, and H. D. Sivinski, Beneficial of Waste Nuclear Isotopes - 137 Cesium Irradiation Treatment of Municipal Sludge and Compost, ERDA 77-17, National Technical Information Service, U.S. Department of Commerce, Springfield, VA, January $5,1977$.

6. U.S. Nuclear Regulatory Commission, Office of Standards Development, Regulatory Guide 6.3 - Design, Construction, and Use of Radioisotope Power Generators for Certain Land and Sea Applications, Nationa 1 Technical Information Service, Springfield, VA 22161.

7. International Atomic Energy Agency, Safety Series No. 33 - Guide to the Safe Design, Construction, and Use of Radioisotope Power Generators for Certain Land and Sea Applications, UNIPUB, New York, NY 10016, $19 \overline{70}$.

8. R. R. Jackson, "Hanford Waste Encapsulation: Strontium and Cesium." Nuclear Technology 32(1):10-15, January 1977.

9. 34 Federal Register 16034, August 9, 1972.

10. J. J. Perona and J. 0. Blomeke, Parametric Study of Shipping Casks for Solid Radioactive Waste, ORNL-TM-3651, Oak Ridge Nationa 1 Laboratory, Oak Ridge, TN, February 1972. 


\section{ACKNOWLEDGMENTS}

Valuable advice and information on isotope heater potential applications, conceptual designs, and associated costs were provided by F. M. Reiff, W. L. Ryan, and L. P. Wallace of the U. S. Public Health Service, Anchorage, Alaska and by B. H. Reid, Environmental Protection Agency - Arctic Environmental Research Laboratory, College, Alaska. The report was edited by J. S. McPherson and typed by P. C. Dunn. 


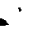




\section{DISTRIBUTION}

No. of

Copies

A. A. Churm

DOE Chicago Patent Attorney

9800 S. Cass Avenue

Argonne, IL 60439

J. N. Maddox

DOE Division of Biomedical and Environmental Research

Washington, DC 20545

G. W. Cunningham

DOE Waste Management Division Washington, DC 20545

C. A. Cooley

DOE Waste Management Division

Washington, DC 20545

D. C. Bauer

DOE Division of Advanced Systems and Materials Production

Washington, DC 20545

T. J. Dobry, Jr.

DOE Division of Advanced Systems and Materials Production

Washington, DC 20545

T. J. Holleman

DOE Division of Advanced Systems and Materials Production

Washington, DC 20545

R. N. Kostoff

DOE Division of Advanced Systems and Materials Production

Washington, DC 20545

A. P. Litman

DOE Division of Advanced Systems and Materials Production

Washington, DC 20545

G. A. Newby

DOE Division of Advanced Systems and Materials Production

Washington, DC 20545
No. of

Copies

W. C. Remini

DOE Division of Advanced Systems and Materials Production

Washington, DC 20545

B. J. Rock

DOE Division of Advanced Systems and Materials Production

Washington, DC 20545

E. J. Wahlquist

DOE Division of Advanced Systems and Materials

Production

Washington, DC 20545

D. C. Davis, Jr.

DOE Oak Ridge Operation Office

P.0. Box E

Oak Ridge, TN 37830

W. T. Goldsten

DOE Savannah River Operations Office

P.0. Box A

Aiken, SC 29801

27 DOE Technical Information Center

J. E. Caldwel1

Alaska Aquaculture Foundation, Inc.

Box 10338

Anchorage, AK 99502

T. E. Humphrey

Alaska Bussell Electric Co.

P.0. Box 41325

Anchorage, AK 99509

W. L. N. Fisken

Alaska Pipeline Service Company

P.0. Box 4-Z

Anchorage, AK 99503 
No. of

Copies

G. W. Boedecker

Alaska Region Office

Federal Aviation Administration

632 Sixth Avenue

Anchorage, AK 99501

R. Freeman

Alaska Region Office

Federal Aviation Administration

632 Sixth Avenue

Anchorage, AK 99501

C. Hoggard

Alaska Region Office

Federal Aviation Administration

632 Sixth Avenue

Anchorage, AK 99501

Dr. J. F. Schindler

Alaskan Resource Sciences

Corporation

2550 Spenard Road

Anchorage, AK 99503

R. C. Gordon

Arctic Environmental Research Laboratory

Environmental Protection Agency

College, AK 99504

R. W. Latimer

Arctic Environmental Research Laboratory

Environmental Protection Agency

College, AK 99504

B. H. Reid

Arctic Environmental Research Laboratory

Environmental Protection Agency

College, AK 99504

W. J. Zielenback

Battelle Columbus Laboratories

505 King Avenue

Columbus, $\mathrm{OH} 43201$
No. of

Copies

W. M. Pardue

Battelle Columbus Laboratories

505 King Avenue

Columbus, $\mathrm{OH} 43201$

B. Ogle, Consultant

3801 West 44 th

Anchorage, AK 99507

K. Waring

Community Planning Division

Department of Community and Regional Affairs

State of Alaska

Juneau, AK 99801

H. W. C. Aamot

Cold Regions Research and Engineering Laboratory

U.S. Army Corps of Engineers

Hanover, NH 03755

H. D. Hollis

Department of the Army

Headquarters, U.S. Army

Facilities Engineering Support Agency

Fort Belvoir, VA 22060

H. Musselman

Department of the Army

Headquarters, U.S. Army

Facilities Engineering Support Agency

Fort Belvoir, VA 22060

L. E. Leonard

Dept. of Civil Engineering

Northern Engineer

University of Alaska

College, AK 99701

E. F. Rice

Dept. of Civil Engineering

University of Alaska

College, AK 99701 
No. of

Copies

J. Reinwand, Deputy Commissioner

Department of Environmental Conservation

419 Sixth Street

State of Alaska

Juneau, AK 99801

J. Sargent

Department of Environmental Conservation

419 Sixth Street

State of Alaska

Juneau, AK 99801

Ms. K. L. Allred

Division of Planning and Research

Office of the Governor

State of Alaska

Juneau, AK 99801

E. H. Cooke-Yarborough

Electronics and Applied Physics Division

Building 347.3, AERE Harwel1

Oxfordshire 0X11 ORA

Great Britain

H. C. Carney

General Atomic Company

P.0. Box 81601

San Diego, CA 92138

P. E. Brown

General Electric Company MSVD

P.0. Box 8555

Philadelphia, PA 18101

G. E. Robinson

General Electric Company,

Vallecitos Laboratory

P.0. Box 846

Pleasanton, CA 94566

J. W. Anstee

Industrial Products Group

Atomic Energy of Canada, Ltd.

Ottawa, Canada
No. of

Copies

D. W. Hood

Irstitute of Marine Science

University of Alaska

College, AK 99504

S. E. Bronisz

Los Alamos Scientific Laboratory

P.0. Box 1663

Los Alamos, NM 87544

R. A. Kent

Los Alamos Scientific Laboratory P.0. Box 1663

Los Alamos, NM 87544

R. N. Mulford

Los Alamos Scientific Laboratory

P.0. Box 1663

Los Alamos, NM 87544

W. T. Cave

Monsanto Research Corporation

Mound Laboratory (DOE)

Nuclear Operations

P.0. Box 32

Miamisburg, OH 45342

R. Dewitt

Monsanto Research Corporation

Mound Laboratory (DOE)

Nuclear Operations

P.0. Box 32

Miamisburg, OH 45342

W. W. Denner

Naval Arctic Research Laboratory Barrow, AK 99723

L. Underwood

Naval Arctic Research Laboratory Barrow, AK 99723

F. E. Rosell

Naval Nuclear Power Unit

Code 70

Port Hueneme, CA 93043 
No. of

Copies

A. A. Arcuni

Naval Facilities Engineering Command

Office of Special Assistant

Nuclear Programs (04N)

200 Stoval1 Street

Alexandria, VA 22332

Head, Reactor Branch

Navy Office of the Chief of

Naval Operations

Washington, DC 20390

R. W. Peddie

Northern Engineering Services

Company, Ltd.

615 6th Avenue S.W.

Calgary, Alberta

Canada

E. Lamb

Oak Ridge National Laboratory

Oak Ridge, TN 37830

A. C. Schaffauser

Oak Ridge National Laboratory

Oak Ridge, TN 37830

F. Reiff

Office of Environmental Health

U.S. Public Health Service

Anchorage, Alaska

W. L. Ryan

Office of Environmental Health

U.S. Public Health Service

Anchorage, Alaska

L. P. Wallace

Office of Environmental Health

U.S. Public Health Service

Anchorage, Alaska

G. Nethercutt

Senator Ted Stevens' Office

01d Senate Office Building

Washington, DC 20545
No. of

Copies

P. Dick

Teledyne Energy Systems

110 W. Timonium Road

Timonium, MD 21093

R. Hannah

Teledyne Energy Systems

$110 \mathrm{~W}$. Timonium Road

Timonium, MD 21093

P. Vogelberger

Teledyne Energy Systems

110 W. Timonium Road

Timonium, MD 21093

C. C. Silverstein

Westinghouse Astronuclear Laboratory

P.0. Box 10864

Pittsburgh, PA 15236

\section{ONSITE}

DOE Richland Operations

W. A. Burns

W. C. Johnson

H. E. Ransom

Rockwel1 Hanford Operations

L. I. Brecke

H. H. Hopkins

L. M. Knights

E. J. Kosiancie

C. W. Malody

J. D. Moore

H. P. Shaw

R. W. Spencer

Battelle-Northwest

R. L. Aaberg

D. G. Atteridge

J. W. Bartlett

W. F. Bonner

L. M. Browne

M. 0 . Cloninger 
No. of

Copies

Battelle-Northwest (cont'd)

J. G. Desteese

G. W. Dawson

H. T. Fullam

J. H. Jarrett

R. C. Liikala

J. L. McElroy

R. W. McKee

R. E. Nightingale

D. E. Olesen

A. M. Platt

10 W. E. Sande

D. S. Trent

H. H. Van Tuyl

R. A. Walter

L. D. Williams

Technical Information Files (5)

Technical Publications 


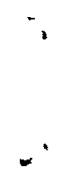

